\title{
The Logistics of Online Clothing Returns in Sweden and How to Reduce its Environmental Impact
}

\author{
Sharon Cullinane, Kevin Cullinane \\ University of Gothenburg, Gothenburg, Sweden \\ Email: sharon.cullinane@gu.se, kevin.cullinane@gu.se
}

How to cite this paper: Cullinane, S., \& Cullinane, K. (2021). The Logistics of Online Clothing Returns in Sweden and How to Reduce its Environmental Impact. Journal of Service Science and Management, 14, 72-95.

https://doi.org/10.4236/jssm.2021.141006

Received: January 5, 2021

Accepted: February 17, 2021

Published: February 20, 2021

Copyright $\odot 2021$ by author(s) and Scientific Research Publishing Inc. This work is licensed under the Creative Commons Attribution International License (CC BY 4.0). http://creativecommons.org/licenses/by/4.0/

\begin{abstract}
Online shopping for clothes continues to increase apace and with it, clothing returns. Returns create a whole logistics flow which has negative environmental consequences. Although there is a growing literature on reverse logistics and returns management, there is little which actually describes and analyses the returns process. Until this is fully understood, a detailed analysis of the environmental impacts of returns is impossible. Through a combination of case-study interviews and a qualitative survey of experts, this paper seeks to illuminate the complexity of the returns process and structures involved and in so doing, suggest ways in which the environmental footprint of returns can be improved. It highlights the joint roles of consumers, retailers and carriers in this process.
\end{abstract}

\section{Keywords}

Returns Management, Reverse Logistics, Clothing, Environment, Online Shopping

\section{Introduction}

Clothing retailing has gone through a transformation over the past decade and the momentum is continuing. More than in any other product sector, there has been a move towards selling online (e-tailing) and, increasingly, omni-channel retailing (Eurostat, 2017; Cullinane et al., 2019). With increased online sales has come an increase in returns; with return rates of up to $60 \%$ in some sub-categories of clothing (such as fashion items) and countries. The returns process incurs considerable environmental costs, which are often neglected in the literature assessing the environmental impact of e-tailing. However, it is difficult to evaluate 
the extent of such costs without a thorough understanding of the structure of the reverse logistics chain. In order to fill this research gap and shed some light on the likely environmental costs of online clothing returns, this paper explores the reverse logistics chain from a retailer perspective. Using qualitative primary data collected from extensive interviews and observations from case-studies of five major clothing companies and two logistics service providers in Sweden, the structure of the observed reverse chains is identified, described and analyzed. The relationship to, and impact upon, the environment is analyzed from the point at which the consumer initiates a return, through transportation, sorting and processing, to the point where the returned product is resold, or otherwise disposed of, by the retailer.

Following a brief introduction to the recent developments in clothing retailing and the complex issues surrounding returns, the paper continues by reviewing the existing literature on returns management, with a focus on reverse logistics. After outlining the methodology applied within the research, the paper then goes on to analyze the reverse chains of the case study companies, with the aim of highlighting the gaps in knowledge and to suggest measures to reduce the environmental impacts. The results reveal the complexity of the reverse chains and the consequent difficulties in evaluating precise environmental costs. By categorizing the measures to deal with the environmental impacts into those associated with the consumer, the retailer and the carrier, a framework for environmental impact reduction is proposed. The potential for utilizing this framework for evaluating environmental cost reduction strategies by retailers and government agencies is then presented. The paper is innovative in developing an understanding of the processes underpinning online clothing returns, since this was previously unknown. On the basis of this understanding and its further analysis, the paper's main contribution lies with the development and recommendation of policies for improving the environmental sustainability of returns.

\section{Recent Developments in Clothing Retailing and Consumer Returns}

The clothing retail sector has changed dramatically over the past decade, with online shopping practically replacing catalogue shopping and making huge inroads into the traditional pattern of shopping in a physical store. The CEO of one major retail company stated that $80 \%$ of customers start their retail journey online (Katz, 2017 quoted in JDA \& Centiro, 2017). The clothing sector now tops the tables of percentages of products bought online in most countries (Statista.com, 2019). In the European Union, 65\% of people aged 16 and older bought an item of clothing online in 2018; by far the most popular category of online purchases (Eurostat, 2020). Barring any fundamental changes to the terms under which goods are sold (and returned), online clothing sales look set to dominate still further in the future. Although still not yet fully operational in most clothing companies, omni-channel shopping, whereby goods are viewed, 
bought and paid for using any combination of sales and marketing channels, certainly looks set to arrive within the next 5 years (Buldeo Rai et al., 2019). Online platforms are making significant strategic moves to capture and increase their market shares of burgeoning online sales in the fashion industry, with Amazon surpassing Macy's in 2018 to become the largest clothing retailer in the US and with JD.com and Alibaba combined controlling more than $80 \%$ of the Chinese clothing market (McKinsey \& Co., 2018). In Europe, Amazon and Zalando are pushing to become the major fashion e-tailing platforms.

Commensurate with an increasing quantity of goods bought online, however, has come an increase in the number of returns. The percentage of clothing items returned varies considerably between categories of clothing and country of sales, but ranges from $10 \%$ for standard basic clothing (such as white T-shirts) to over $60 \%$ for high fashion goods. There is also evidence of demographic (e.g. gender, age and income) differences (Harris, 2010; Klarna, 2019; IMRG, 2020).

The growth in online shopping for clothing has been accompanied by a change in consumer purchasing behavior. A recent study has shown that $44 \%$ of customers in the UK order with a view to returning at least part of the order (Thomas, 2017). In Sweden, a survey for JDA and Centiro (2017) showed that $13 \%$ of online customers had ordered several items with the intention of sending some back; a phenomenon which has been termed "retail borrowing", "wardrobing" or sometimes "renting". Consumer surveys by Piron and Young (2000) and Rosenbaum and Kuntze (2005) both found that around 20\% of consumers were buying goods with the express purpose of using and then returning them. A global consumer survey conducted by JDA and Centiro (2018) revealed a worldwide average of $27 \%$ of online customers buying with the intention of making returns. A more recent global survey by Metapack (2020) found that over $40 \%$ of respondents between the age of 21 and 44 had bought clothing items knowing that they would return some items. A survey of customers making returns in the UK carried out by IMRG (2020) found widespread use of "bracketing", i.e. customers buying one size larger and one size smaller as well as the size they consider themselves to be. A report by Barclaycard (2018) found that $10 \%$ of consumers who bought clothing online in the UK bought it with the express purpose of taking a digital photograph, posting it on social media and then returning the goods without having worn them. These over-ordering behavior patterns are encouraged both by the policy of many retailers to offer free returns and by EU legislation which allows customers to return their purchases within 14 days of purchase for no reason whatsoever and receive a full refund (European Commission, 2017).

There are many reasons why clothing items might be returned. On the basis of a consumer survey, Rosenbaum and Bitner-Olson (1999) categorised returners into five types:

- Sport returners saw making returns as fun;

- Unethical returners made mostly fraudulent returns;

- Ethical returners only returned goods when they thought there was a good 
reason for doing so;

- Classic returners returned goods that they received as gifts and;

- Educated returners made a point of knowing the returns policies of retailers and felt little guilt in making returns.

More recently, Saarijärvi et al. (2017) reviewed the literature on consumer returns before carrying out their own survey, specifically relating to the fashion industry. They categorized consumer returning behavior into the following:

- reclamation (defective products),

- order-fulfilment (wrong products being delivered),

- competition (finding a better offer elsewhere)

- disconfirmation (an unexpected feature of the product)

- size chart (wrong size)

- feeling (product just not feeling right)

- money shortage (not having money to pay for the product)

- benefit maximization (ordering multiple items to find a suitable one)

- Just trying out (to see what the product is like, with no real intention of buying).

They also identified phases in the consumer ordering process during which the decision was made by the consumer to return the product, emphasizing that in many instances the decision to return a product was made before the order was made.

A further important issue in relation to this paper is that a substantial and increasing percentage of clothing items bought online are purchased cross-border, see Kim et al. (2017) and Cullinane and Cullinane (2018) for reviews on this topic. In Europe in 2019, 23\% of e-shopping purchases were cross-border, compared to $11 \%$ in 2011, an increase of more than $100 \%$ in eight years (E-commerce Europe, 2019). Citing data from Paypal and Ipsos gathered in 2016, around 50\% of e-shoppers worldwide made a cross-border purchase of clothing, apparel, footwear or accessories; more than for any other category of goods (eMarketer, 2016). In his report on worldwide cross-border sales, Frederick (2015) also notes that clothing is by far the most frequently purchased product category.

There is an inevitable cost to the environment of this returns activity. Although there is a growing literature on the environmental impact of e-commerce (for instance, see the reviews by Cullinane (2009) and Mangiaracina et al. (2015)), most of this literature fails to take into account the returns activity. Simply put, the environmental impact of returns is essentially dependent on a) the number of returns that are made and b) the journeys and processes they endure. We need, therefore, to consider both. The literature review which follows will cover the wider area of returns management, as well as the more specific element of reverse logistics.

\section{Literature Review}

\subsection{The Returns Management Context}

Several works, including Rogers and Tibben-Lembke (1998), Schwartz (2000) 
and Hjort et al. (2019), explicitly recognise a returns management process that includes five essential activities: avoidance (or mitigation), gatekeeping, collection, sorting and disposal. Other works, for example Lambert et al. (2011) and Daaboul et al. (2014), implicitly recognize this conceptualization of returns management, by analyzing disaggregated versions of some of the five essential activities. Most notably, the "disposal" activity is often disaggregated into sub-activities such as resell, remanufacture, recycling, landfill etc. (e.g. de Brito \& Dekker, 2003). The five essential activities of the returns management process may be defined as follows.

- Avoidance (or mitigation) refers to measures put in place by retailers which make it unnecessary for customers to return goods in the first place. This could be through efforts to improve the image visualization on the website, increasing the number of photographs and descriptions of the various accessories on the clothing (buttons, zips stitching etc), Artificial Intelligence (AI) applications such as customer profiling, virtual reality (VR) measures such as digital changing rooms, chat lines etc.

- Gatekeeping refers to the point of entry into the reverse logistics system. This could be defined in terms of a monetary value (e.g. only products worth over $€ 10$, or only products where the return value exceeds the postage) are sent back up the supply chain, or some other criterion. This step is critical since it revolves around the decision as to whether or not a product will enter the returns process and is thus important for the manageability and profitability of the reverse flow.

- Collection is concerned with collecting the returned products from the end-customer (Daaboul et al., 2014). According to Lambert et al. (2011), collection involves two stages; the pick-up of the returned product and its transportation. This can be done by the e-tailer, a third-party logistics provider or the customer themselves (for instance, by returning products to stores), depending on several factors including the structure of the company, the complexity of the product, the reason for the return and the territories involved, among others (Lambert et al., 2011). This is the stage that is obviously most closely aligned to reverse logistics.

- Sorting involves deciding the fate of the collected product. It involves inspection of each returned item individually. It is this process that adds so much to the cost of reverse logistics, as it a process that must be carried out manually and may involve further processes such as ironing or cleaning.

- Disposal is the exit of the reverse logistics system. A large proportion of the items will be distributed back to the stores or customers, as new. A further proportion will be sold through discount stores or outlet centers. Products which are difficult to place through these channels will be donated to charity and the final, usually very small proportion, may be sent to landfill or will be recycled by specialists in this field. In contrast to the other stages, this final stage, sometimes referred to as "asset value recovery", can actually generate revenues and could be viewed as the main goal of this activity (Lambert et al., 
2011).

There now exists a reasonable body of academic literature on various aspects of returns management. It includes the more managerial/financial aspects of value creation, as well as customer behavior and customer psychology, all of which are relevant to each of the five activities that constitute returns management.

- Value creation concerns the relationship between returns and corporate profitability (see for example Mollenkopf \& Closs, 2005; Mollenkopf et al., 2011; Alumur et al., 2012; Hjort \& Lantz, 2016; Larsen \& Jacobsen, 2016). With the return rate being so high, it is unsurprising that there is a substantial literature on ensuring that companies extract the greatest value from their returns. In 2016, the Research Director of Gartner Research in the US (quoted by Reagan, 2016) called returns "a ticking time bomb turning into a major cash hole".

- Customer behavior covers topics such as whether or not serial returners make better customers (Petersen \& Kumar, 2009; Ramanathan, 2011; Griffis et al., 2012; Hjort et al., 2013) and the effects of pricing policies and conditions on returns (Suwelack et al., 2011; Bower \& Maxham III, 2012; Kim \& Wansink, 2012; Pei et al., 2014; Janakiraman et al., 2016; Shang et al., 2017).

- Customer psychology relates to issues such as how focused the customer is on making the return (Janakiraman \& Ordonez, 2012).

\subsection{Reverse Logistics}

The Reverse Logistics Association defines reverse logistics as: “...the process of moving goods from their typical final destination for the purpose of capturing value, or proper disposal" (RLA, 2016). In some ways this definition is rather limited. It is perhaps improved by Rogers and Tibben-Lembke (1998: p. 2) as being "...the process of planning, implementing and controlling the efficient cost-effective flow of raw materials, in-process inventory, finished goods and related information from the point of consumption to the point of origin for the purpose of recapturing or creating value or proper disposal".

Dekker et al. (2004) identified three major areas of research in reverse logistics-management of the recovery and distribution of end-of-life products; production planning and inventory management and supply chain management issues. In their review paper, Rubio et al. (2008) sought to categorize the papers written on reverse logistics between 1995 and 2005 using the categorization of Dekker et al. (2004). They categorized 186 articles in 26 journals. It is interesting to note that none of the categorized papers made more than a passing reference to the environmental impact of reverse logistics as a whole. This is undoubtedly because the papers referred to in both the above reviews could be classed under the heading of "manufacturing logistics", where the environmental focus is skewed towards the disposal (disposition) activity, as befits a product life-cycle perspective. Wang et al. (2017) carried out a bibliometric analysis of reverse lo- 
gistics research between 1992 and 2015. They identify "green logistics/sustainability" as being a key reverse logistics theme, but most of the research identified under this heading relates to social and economic sustainability, rather than environmental sustainability.

As stated above, it is somewhat surprising that there is little research on the wider environmental impact of reverse logistics (particularly those elements pertaining, either directly or indirectly, to distribution) and how this relates to the structure of the reverse logistics chain. In their seminal report on reverse logistics, Rogers and Tibben-Lembke (1998) devote a 36-page chapter to reverse logistics and the environment. However, half the chapter is devoted to landfill issues and the other half covers transport packaging. It completely omits any consideration of the wider environmental impact of the reverse logistics process.

\subsection{Our Approach}

The distinction that exists between reverse logistics and returns management is that the former is held to constitute a separate and identifiable element of the latter. This distinction has been described by Hjort et al. (2019) as being "paradigmatic" and they assert that it has subsequently been closely adhered to in the literature. However, this defined distinction is not always very clear, since the five elements that together comprise returns management (three of which comprise reverse logistics) are neither discreet nor independent of each other; a change in either of the other two elements that comprise returns management will have an impact or knock-on effect on the reverse logistics element. For instance, a reduction in a company's returns which takes place as a result of an improvement in the quality of the website visualisation will have an impact on the number of returns and thus the extent, and perhaps the nature, of the reverse logistics. Other potential interactive effects between the five elements that comprise returns management can be identified. As a consequence, therefore, the underlying approach to the research reported herein has not been restricted solely to a silo-like analysis of reverse logistics as a discreet and independent element or pillar of returns management. Instead, a more holistic and non-discriminatory perspective has been adopted which encompasses the analysis of the wider returns management field, but with a specific focus on the implications for, and potential impact upon, the reverse logistics element.

In its most stringent form, reverse logistics is defined as comprising the three returns management activities of "collection", "sorting" and "disposal" (Rogers \& Tibben-Lembke, 1998; Croxton et al., 2002; de Brito \& Dekker, 2003; Hjort et al., 2019), as described in the previous section. However, the "gatekeeping" activity is also sometimes included as part of reverse logistics (e.g. Daaboul et al., 2014). This alternative conceptualisation is understandable in that the gatekeeping activity involves a decision making process that may or may not initiate a return and, hence, can be seen to be the required initial trigger for the three mainstream reverse logistics activities of collection, sorting and disposal that follow it. It is also the case that at least some part of the gatekeeping activity may 
take place after a customer has already initiated a return; for example, when a decision on accepting a return is made at a warehouse, rather than at a shop. Irrespective of whether the gatekeeping activity is considered a part of reverse logistics or not, it is absolutely the case that all three mainstream reverse logistics activities are impacted by both avoidance and gatekeeping activities and, as such, a change in any one of these elements will have an impact on the mainstream reverse logistics activities and, therefore, on the environment. Figure 1 presents a diagrammatical summary of this theoretical framework.

It is only by disaggregating the returns management process into its component parts and identifying the structure of the entire returns supply chain that its comprehensive environmental impacts can be properly assessed and effective environmentally sustainable policies developed in relation to returns.

\section{Methodology}

The review of the literature reveals a significant focus on concepts and taxonomy, but little detail on the problems that companies encounter in practice as a result of a high, and increasing, level of returns. Observations gleaned from the trade press suggested that the majority of companies were dealing with returns in a largely unstructured way. This was reflected in the general reverse logistics literature, where assumptions were being made as to the structure of the reverse chains which had been put in place. Obviously, the inappropriateness of any assumptions made concerning the structure of reverse logistics could lead to erroneous recommendations and conclusions. This shortfall in information and knowledge on the structure of reverse logistics chains represents a research gap

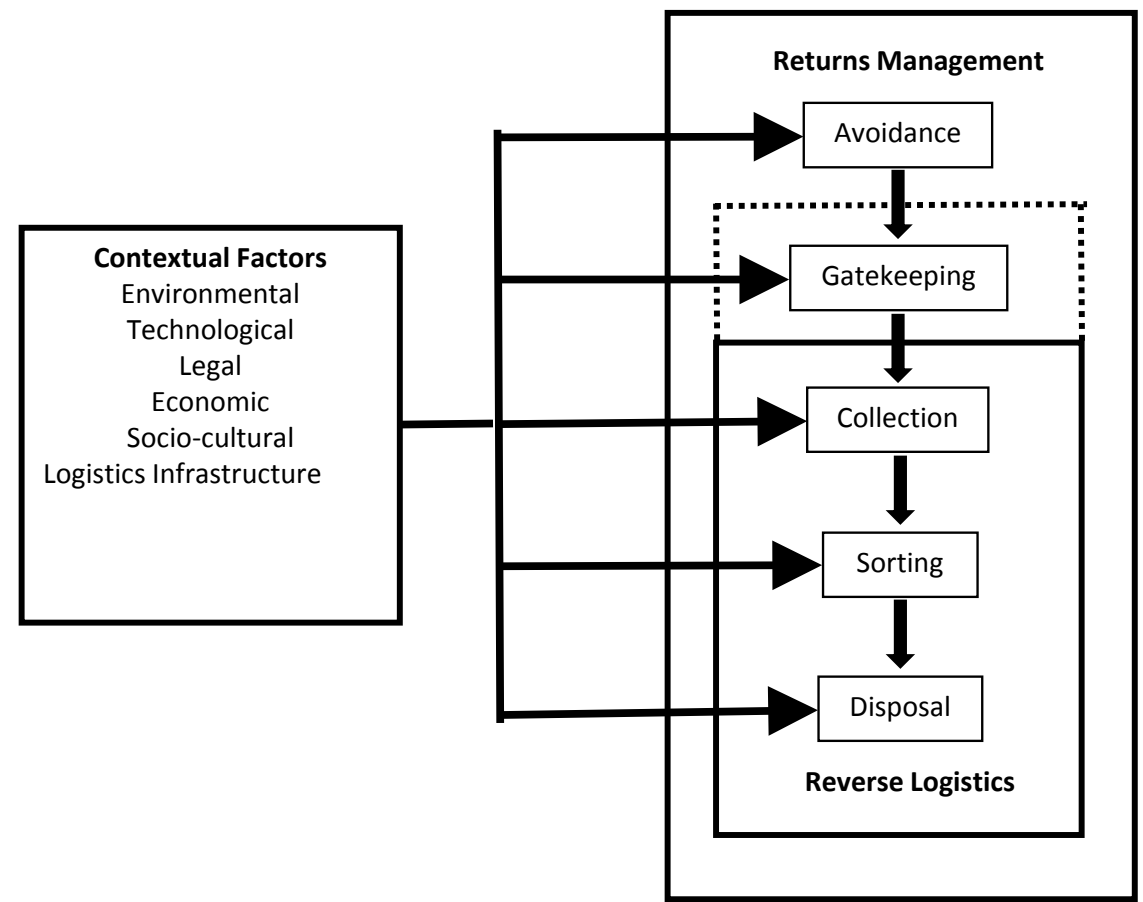

Figure 1. Overall theoretical framework of returns management and reverse logistics. 
that this paper seeks to fill and, in so doing, brings into question the accepted wisdom as to the likely scale of the un-costed environmental consequences of reverse logistics.

In order to really explore what is happening in practice, a qualitative, interpretative research approach using case studies was deemed appropriate. Case studies can be used to explore a particular research question and to investigate the underlying factors that affect a specific outcome (Bryman \& Bell, 2007; Creswell, 2014; Yin, 2014). Over a period of four months, in-depth semi-structured, face-to-face interviews were conducted with five major clothing retailers and two major logistics service providers in Sweden (Postnord, the national carrier and a major regional carrier). Because some of the information obtained from the sample companies was deemed to be commercially sensitive, all but one required that their identity not be revealed. However, the sample can be characterised as follows. The retail case study companies ranged from fairly small (around 100 employees) to some of the largest in Sweden (>100,000 employees). Three of the retailers had physical stores as well as a large online presence and two were pure online companies. All companies traded internationally, with clothing representing the largest part of sales volume in each case.

Interview schedules were developed in advance to guide the interviews. In each case, a semi-structured interview protocol outlining issues for discussion and questions to be answered was sent to the company before the visit. However, interviewees were given a great deal of flexibility within the interviews to develop their arguments and viewpoints and there was no predetermined question order. Observations of the returns management and reverse logistics operations in these companies also took place. The interviews were very detailed, lasting between 3 and 6 hours. In the case of the largest retailer, the country manager alone was interviewed, while in the other companies between 5 and 10 people in each were interviewed, from the CEO down to returns managers, operatives and warehouse staff. The intention of this approach was to gain representative views from all organisational levels and to triangulate those views.

The discussions were very wide-ranging and a great deal of information was obtained. Typically, the scope of the discussions covered: 1) each company's strategic approach to dealing with returns; 2) the specifics of their returns policies and operations; 3 ) the historical, and likely future, development of returns policies; 4) company priorities and what was considered important with respect to returns and; 5) the corporate attitude towards the environment. Three members of the research team were present at all of the case study visits. The interviews were digitally recorded and subsequently transcribed in order to be able to avoid the difficulties associated with taking notes during an interview.

One important aspect to emerge from the discussions was that companies had little detailed information about their returns, so could not present a comprehensive and consistent set of data that would enable detailed, generalizable and comparable calculations of the economic or environmental cost to be made across the multiple companies and chains involved. The discussions did yield, 
however, a great deal of rich, qualitative information. The wide range of discussion topics included, but was not confined to, the following:

- The current process of dealing with customer returns, domestically and internationally

- The journeys made by the returned products

- The historical development of the current returns process and how and why had it evolved

- The main company objectives related to returns

- The discussant's/company's attitude towards the environmental aspects of returns

- The desired future development in relation to returns

- The main barriers to achieving their objectives in relation to returns and the environment.

Due to the quantity and quality of the information obtained in the interviews, mapping of the returns at a more aggregate level was carried out for each company, along with an analysis of the evolution, development and reasons behind the particular structures which emerged from each company. This enabled the construction of a returns framework specifying the key actors, themes and measures.

During the course of the interviews, it had become apparent that the sheer scale of the returns was unanticipated by the retailers and that they were only just appreciating the impact of this on company profitability. Dealing with returns was not the job/responsibility of any one manager in particular, as it had not yet been built into the companies' management structures. However, when asked about returns in the interviews, all interviewees said it was becoming one of their top priorities and allocated an importance score to it of 9 , or even 10, out of 10 .

Seeking to apply a mixed method design to the data collection process (Modell, 2010; Golicic \& Davis, 2012; Harrison III, 2013) in an effort to both supplement and enhance the case-study data that had already been collected, consultations with numerous industry and academic experts were implemented following the case-study research. On the basis of these discussions, it was decided that the response rate to a follow-up large-scale quantitative questionnaire survey would be too low. It was ultimately decided, therefore, to implement a more qualitative survey, exploring the emergent themes from the first phase of the data collection process in terms of their importance and their feasibility. The target for the survey included the interviewees from the first phase case-study companies, together with a select group of international academic and industry experts in the field. In this way, the questions could be deep and probing and could cover the topic in much more detail than would be possible in a quantitative survey.

Based on the collation and analysis of the case-study interviews, a number of dimensions emerged that informed the development of a questionnaire survey targeting respondent opinions on what would be the most effective ways of reducing the energy and environmental impact of returns. It also provided a 
means of testing the interview results, enlarging the volume of sample responses and obtaining a wider perspective on interview outcomes. Crucially, the questionnaire survey adopted a stance of "this is how it is currently; how can it best be improved?". Following piloting, the questionnaire survey was subsequently sent by email to 49 international "experts", including the original interviewees. Following two reminders, 23 usable responses were received.

\section{Empirical Results}

\subsection{Case-Studies}

The structure of the observed reverse chains varies extensively, with all companies having multiple structures. Within each company, the structures differ significantly according to the country from which the returns originate. These differences can be explained by variations in the company's historical development within the country, as well as by the influence of country-specific laws and consumer behavior patterns. The observed structures can be divided into seven alternatives that are described in Table 1 and then categorized and presented diagrammatically, as shown in Figure 2.

Table 1 and Figure 2 together illustrate some of the complexities of the reverse logistics chain structures, ranging from the simplest (structure 1) to the most complex (structure 7). Structures 5 - 7 involve cross-border returns processing that sometimes involve long journeys by heavy goods vehicle and/or sea transport. As well as providing some summary information on the retail case companies, Table 2 shows the different reverse logistics structures which they employ.

The complexity of the structures used by each individual company is difficult

Table 1. Observed structures for reverse logistics.

1 Returns of items bought online are sent directly back to the retailer in the "home" country by the customer in the "foreign" country.

2 A retailer has both an online and physical store presence in the "foreign" country and some goods are returned directly back to the store.

3 A retailer has a warehouse in the "foreign" country and returns are sent to the warehouse, where the sorting and disposition tasks are dealt with.

A retailer has a warehouse in the "foreign" country where returned goods are simply

4 consolidated before being sent back to the "home" country, where sorting and disposition decisions are made.

As (4) but returns are merely re-consolidated in the "home" country before being sent to a

5 third (probably low cost) country within the EU for sorting and disposition before being sent back again to the "home" country.

6s (4), but following the consolidation of returns in the "foreign" country, they are transferred

direct to a third (probably low cost) country within the EU for sorting and disposition.

As (5) or (6), but where, for some element of the process, products are transferred

7 intercontinentally to a third (and maybe fourth) low cost country outside the EU for (part of) the sorting and disposition process. 


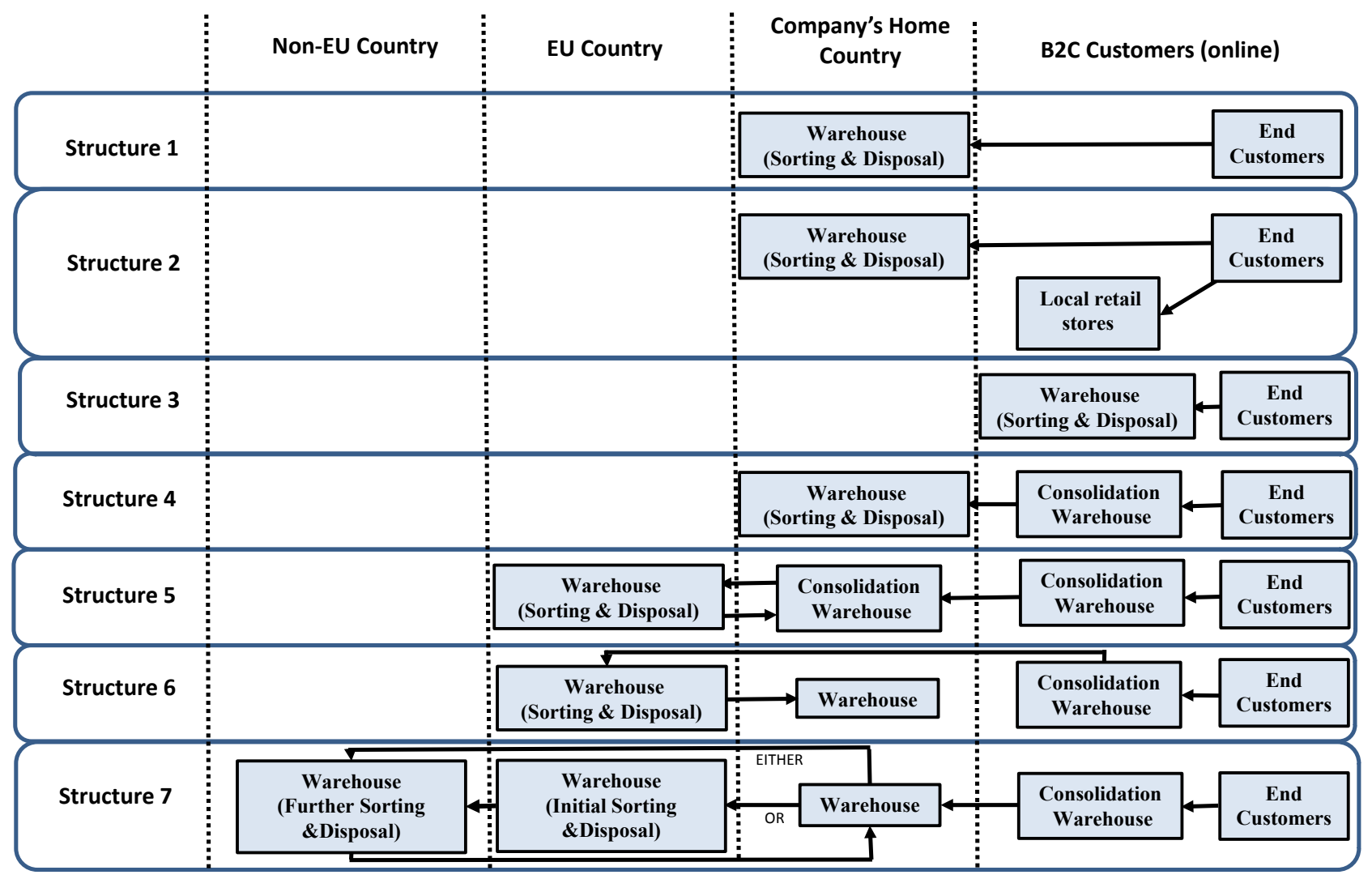

Figure 2. The reverse chain structures used by the case companies. Source: Modified by authors, based on Cullinane et al. (2018).

Table 2. Retail case companies use of observed structures for reverse logistics.

\begin{tabular}{cccc}
\hline $\begin{array}{c}\text { Retail Case } \\
\text { Company }\end{array}$ & $\begin{array}{c}\text { Size (number of } \\
\text { employees worldwide) }\end{array}$ & $\begin{array}{c}\text { Physical } \\
\text { Stores? }\end{array}$ & $\begin{array}{c}\text { Reverse Logistics Structures Used } \\
\text { (from Table 1 and Figure 2) }\end{array}$ \\
\hline 1 & 5000 & Yes & 2,3 \\
2 & $>100,000$ & Yes & $3,4,6$ and just starting to experiment with 2 \\
3 & $>100$ & Yes & 1, just starting to experiment with 2 \\
4 & 200 & No & $4,5,6$ \\
5 & 700 & No & $5,6,7$ \\
\hline
\end{tabular}

to appreciate and describe since they vary so much, depending on country of sale. Figure 3 illustrates the structure used by retail case company 5 in relation solely to their Nordic operations.

From Table 1 and Table 2 and Figure 2 and Figure 3, it is clear that the reverse chains for clothing returns are highly diverse and complex. The most important factor here, however, is not necessarily the individual descriptions of the actual structures employed within the retail case companies, but rather the revelation that there exists such variation in the structures of the reverse logistics chains that are employed. Despite their relative significance to the national context, the results in this paper are limited to just five retail case studies. In no way can the results be claimed to be wholly representative of even the whole clothing 


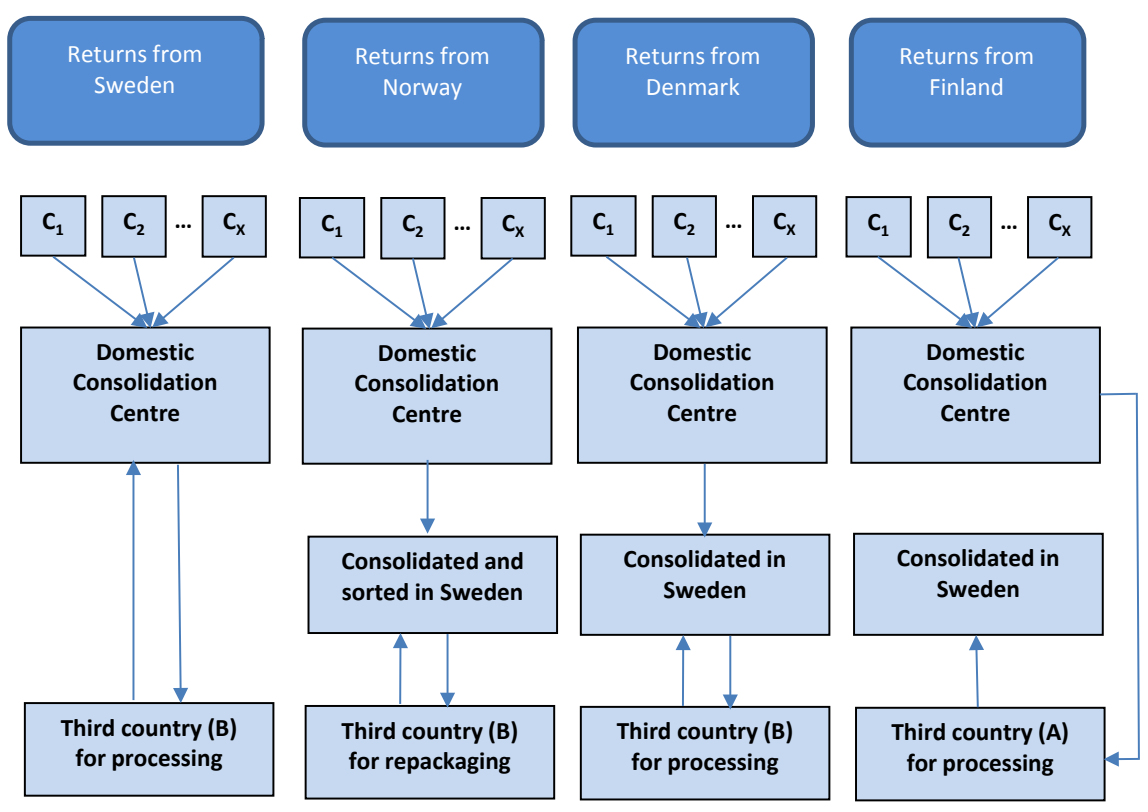

Figure 3. Company 5-Nordic returns operations.

sector in Sweden, let alone the situation in other countries. Despite this, on the basis of informal discussions with companies elsewhere and as frequently evidenced in the content of the trade press, it is clear that the results of the analysis presented herein are not unique, either sectorally or geographically.

Based on the results above, it can be inferred that the environmental consequences of the reverse logistics process are considerable. Returns are sometimes being transported very long distances between various links in the chain, by a combination of heavy goods vehicle and ship, and many are crossing international borders. It is clear from discussions with interviewees that the heavy goods vehicles are not always fully loaded, since reducing stock replenishment lead time is sometimes more important than receiving full loads of goods; that is, the company processing the returns cannot wait until vehicles are full, otherwise stock cannot be turned around quickly enough at the retailer's warehouse. Speedy stock replenishment is particularly essential in the high fashion sector, where particular lines may only stay relevant for weeks before they become outdated and must be sold at a discount (Remy et al., 2016).

However, although the environmental effects of returns are likely to be considerable and are likely to increase in line with increases in online shopping, because of the complexities of the returns chains, the initial goal of trying to calculate and attribute an exact environmental footprint to every possible alternative reverse chain within each company becomes questionable. The meaning, relevance and policy implications of such a myriad of alternatives and associated calculations are not exactly clear. Instead, a more qualitative, policy-orientated solution is decided upon, whereby the focus is changed from the question "what is the environmental footprint?" to "what is the best way to reduce the environmental footprint?" Recordings of the case-study interviews were subsequently 
scrutinized for information on this question.

The discussant responses are summarized in Figure 4, which suggests that the first major categorization of measures lies between those are under the control of the retailer and those that relate more to the consumer in terms of their travel in the course of making the return (i.e. as manifest in the division between retail logistics and consumer logistics).

Figure 4 provides, therefore, a detailed categorization of the potential measures that may be deployed to reduce the environmental footprint of the fashion returns process in Sweden. It points to the fact that the three major targets for measures should be to: 1) reduce the number of returns; 2) Improve the efficiency of returns and; 3) improve the environmental impacts of the assets used. As also shown in Figure 4, each of these three major targets comprises some more specific subcategories of measures (eight of them in total across the three major targets) which can be implemented to help achieve these targets. As emerging from the interviews with case-company discussants, some detailed examples of the sort of specific individual measures that can be implemented within each of these eight subcategories of measures can be seen in Figures 5-7.

\subsection{Results from Questionnaire Survey}

The purpose of the questionnaire survey was to reveal which measures the respondents considered to be most important and feasible in reducing the environmental impact of reverse logistics. Interestingly, there was very little agreement between the respondents as to which activity, retail logistics or consumer travel, had the greatest potential to reduce the environmental impact. There was also no agreement on whether the greatest potential for environmental improvement could be made from reducing the number of returns, improving the efficiency of the returns process or improving the environmental specifications of the assets used (e.g. vehicles, warehouses etc.). The total lack of agreement is interesting in itself and perhaps highlights the lack of focus on returns generally.

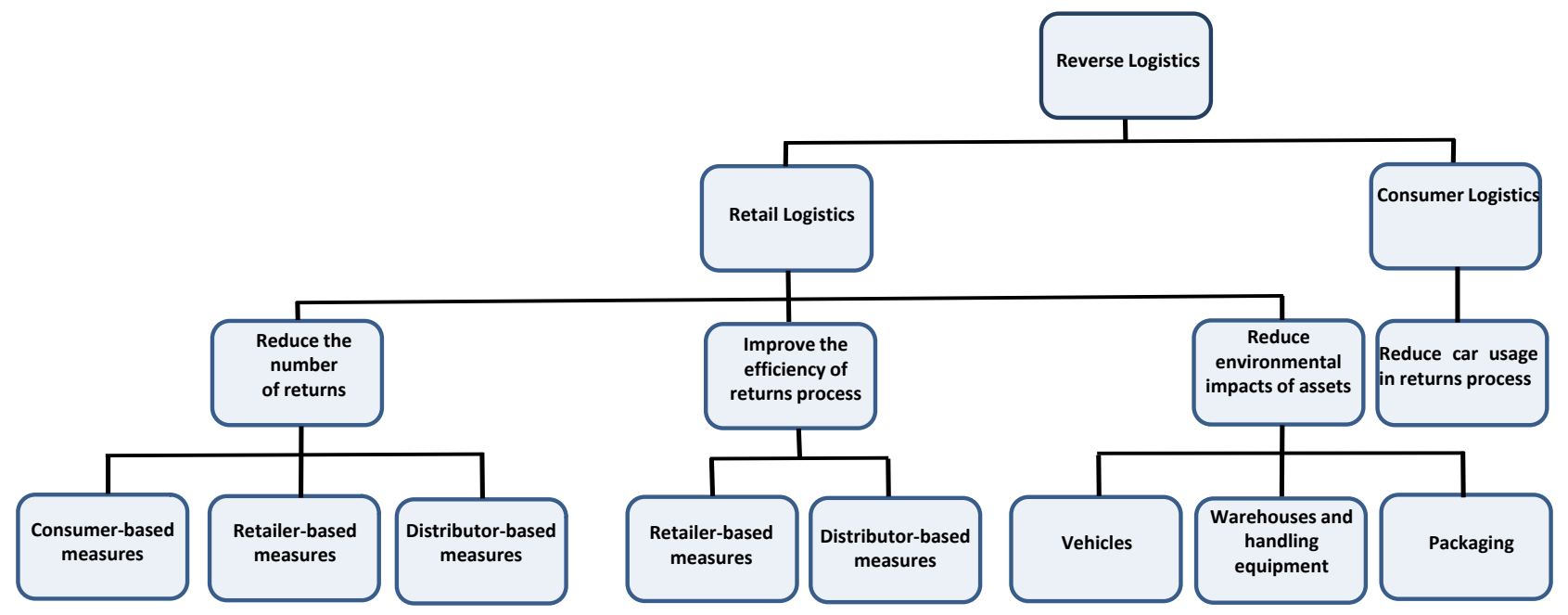

Figure 4. Hierarchy of measures reducing the negative environmental effects of reverse logistics. 
Box A

Consumer-basedmeasures

- Education to inform consumers of environmental consequences of returns

- Increase product customisation and curation

- Improve pre-purchase customer support

- Consider refunds policy (e.g. refunds without returns for good customers)

- Discourage over-ordering

Box B

Retailer-basedmeasures

- Improve quality and accuracy of information on website

- Fewer order mistakes

- Improve returns tracking and tracing

- Returns pricing policy

- Digitalisation provision (e.g. digital changing rooms)

- Consider packaging policy to minimise damage (whilst reducing environmental impact)

\section{Box C}

\section{Distributor-basedmeasures}

- Fewer delivery mistakes

- Reduce in-transit damages

- Improve communication with customer to reduce failed pick-ups

- Consider unattended residential pick-up options

Figure 5. Reducing the number of returns.

\section{Box D}

\section{Retailer-basedmeasures}

- Use of ICT for tracking and tracing to improve end-to-end product visibility and lead times

- Use of ICT in sorting process to increase stock replenishment speeds

- Use of ICT to intercept returns at earlier stage in the returns process to redirect products to new customers

- Consider the disposition options for dealing with returns that cannot be resold 'as new'

- Consider strategic issues such as the location of returns processing generally, including both international facilities and the provision of more local returns 'stores'

Box E

Distributor-basedmeasures

- Increased consolidation/cooperation with other distributors

- Improved use of ICT for tracking and tracing

- Consideration of strategic logistics issues (such as the use, operation and location of warehouse/consolidation centers)

Figure 6. Improving the efficiency of the returns process.

Figure 8 shows the conceptual matrix that was devised to depict the results of the questions relating to the importance/feasibility of the various measures proposed. 


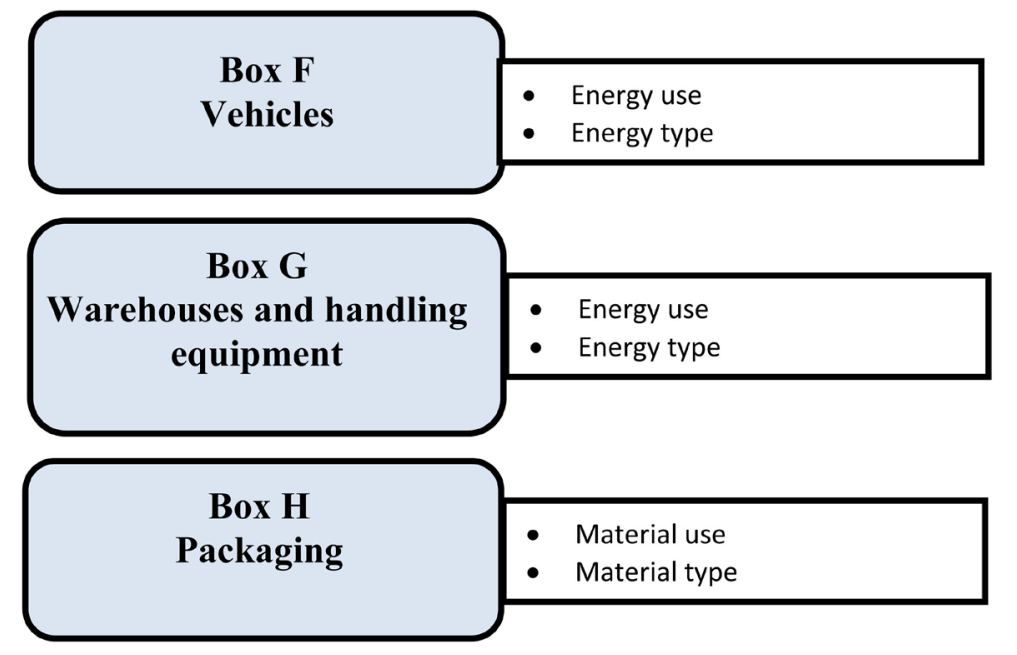

Figure 7. Improving the environmental credentials of the physical assets and their use.

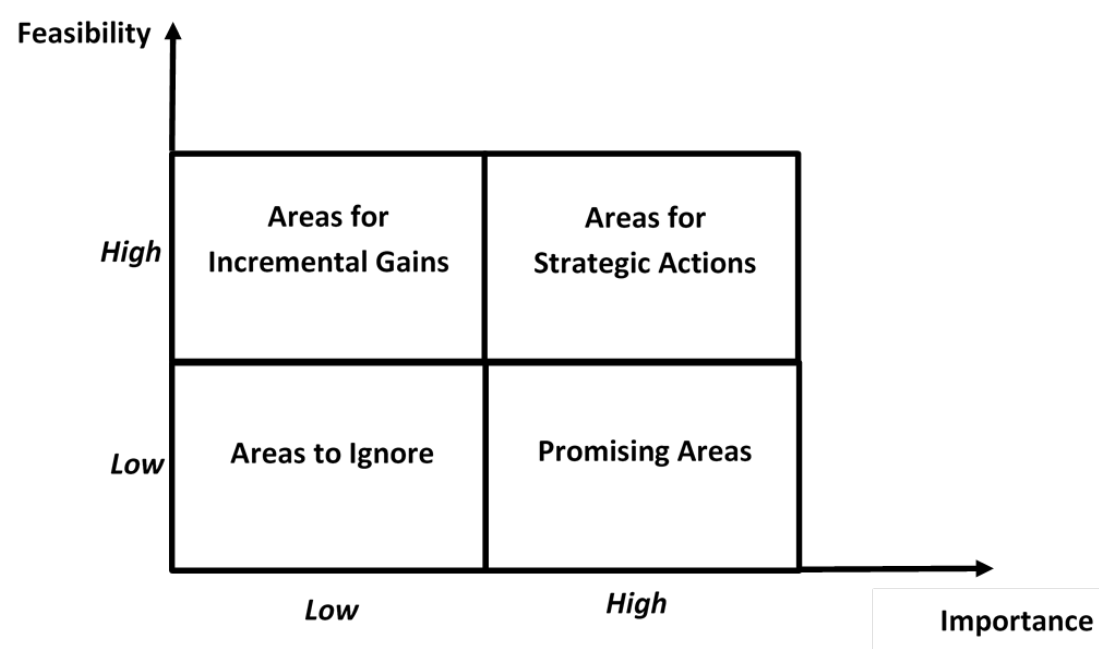

Figure 8. Matrix depicting the importance/feasibility quadrants.

The outcomes from the questionnaire survey are depicted within Figure 9, illustrating that the areas for strategic actions (where both feasibility and importance are high) centre broadly around the customer-retailer and customer-carrier communications interfaces. Table 3 presents the top 5 measures in terms of importance and in terms of feasibility. As is clearly shown by Table 3, while changing the energy source of vehicles is perceived as the most important measure, it does not even appear among the top-ranked feasible measures. In contrast, improved interaction with customers, most especially through company websites, is clearly perceived as being both important and feasible to implement.

Bringing together the responses to the questionnaire survey (including any additional comments made by the respondents) and the outcomes of the case-study analysis, Table 4 summarizes the range of possible measures that can be implemented by the various actors. As customers were not included in the qualitative survey, the "customers" column is particularly heavily influenced by the comments made in discussion with the case-study logistics companies. As such, the 
Table 3. The top 5 measures in terms of importance and feasibility (mean scores out of 5 in brackets).

\begin{tabular}{|c|c|c|c|}
\hline Top 5 measures in terms of importance & Importance ranking & Top 5 measures in terms of feasibility & Feasibility ranking \\
\hline Changing energy type in vehicles (4.8) & 1 & $\begin{array}{l}\text { Improved quality and accuracy of information on } \\
\text { website to reduce the number of returns }(4.5)\end{array}$ & 1 \\
\hline $\begin{array}{l}\text { Increased consolidation/cooperation } \\
\text { with other carriers to improve efficiency }(4.5)\end{array}$ & 2 & $\begin{array}{l}\text { Improved education to inform consumers of the } \\
\text { environmental impact of their returns }(4.2)\end{array}$ & $2=$ \\
\hline $\begin{array}{l}\text { Improved quality and accuracy of information } \\
\text { on website to reduce the number of returns }(4.4)\end{array}$ & 3 & $\begin{array}{l}\text { Increased use of tracking and tracing to improve } \\
\text { end-to-end product visibility and lead-times ( } 4.2)\end{array}$ & $2=$ \\
\hline $\begin{array}{l}\text { Improved operational aspects } \\
\text { (e.g. vehicle fill) to improve efficiency }\end{array}$ & $4=$ & $\begin{array}{l}\text { Improved communications with consumers } \\
\text { to reduce failed pickups }(4.2)\end{array}$ & $2=$ \\
\hline \multirow[t]{3}{*}{$\begin{array}{l}\text { Improved communications with } \\
\text { consumers to reduce failed pickups (4.3) }\end{array}$} & $4=$ & $\begin{array}{l}\text { Increased use of tracking and tracing in } \\
\text { improving carrier efficiency }(4.1)\end{array}$ & $5=$ \\
\hline & & $\begin{array}{l}\text { Increase returns tracking and tracing to } \\
\text { reduce the number of returns by retailers }(4.1)\end{array}$ & $5=$ \\
\hline & & $\begin{array}{l}\text { Improve pre-purchase customer support } \\
\text { to reduce the number of returns }(4.1)\end{array}$ & $5=$ \\
\hline
\end{tabular}

Table 4. Measures to reduce energy use and improve environmental sustainability of returns, by actor type.

\begin{tabular}{|c|c|c|}
\hline Customers & Retailers & Carriers \\
\hline Reduce over-ordering & Increase level of consumer analytics & $\begin{array}{l}\text { Increase level of } \\
\text { cross-company }\end{array}$ \\
\hline Reduce order mistakes & $\begin{array}{l}\text { Improve real-time visibility of } \\
\text { products in reverse chain }\end{array}$ & consolidation \\
\hline $\begin{array}{l}\text { Reduce ill-considered orders } \\
\text { (either not picked up or sent } \\
\text { back before opening or use) }\end{array}$ & Increase consumer returns price & $\begin{array}{l}\text { Use "greener" modes of } \\
\text { transport }\end{array}$ \\
\hline Reduce fraudulent returns & $\begin{array}{l}\text { Reduce number of times items } \\
\text { handled }\end{array}$ & $\begin{array}{l}\text { Use "greener" warehouses } \\
\text { and handling equipment }\end{array}$ \\
\hline $\begin{array}{l}\text { Choose sustainable carriers } \\
\text { (where possible) }\end{array}$ & Increase accuracy and quality of photos & $\begin{array}{l}\text { Reduce distance to and } \\
\text { between consolidation points }\end{array}$ \\
\hline Tolerate increased lead times & $\begin{array}{l}\text { Increase accuracy and quality of } \\
\text { product information }\end{array}$ & Improve network design \\
\hline $\begin{array}{l}\text { Reduce distance travelled to } \\
\text { pick-up point }\end{array}$ & $\begin{array}{l}\text { Improve pre-purchase customer } \\
\text { service }\end{array}$ & $\begin{array}{l}\text { Improve operational } \\
\text { efficiency of logistics } \\
\text { processes }\end{array}$ \\
\hline Use "greener" modes of travel & Increase customisation of products & \\
\hline $\begin{array}{l}\text { Increase level of trip-chaining } \\
\text { in travel associated with } \\
\text { returns }\end{array}$ & $\begin{array}{l}\text { Improve information regarding } \\
\text { sustainability of returns }\end{array}$ & $\begin{array}{l}\text { Improve visibility of } \\
\text { products in the returns } \\
\text { system }\end{array}$ \\
\hline \multirow[t]{5}{*}{ Use appropriate packaging } & Monitor social media & $\begin{array}{l}\text { Improve communications } \\
\text { with other actors in the }\end{array}$ \\
\hline & Monitor customer feedback reports & system \\
\hline & Make fewer order mistakes & Reduce in-transit damage \\
\hline & Increase range of returns options & $\begin{array}{l}\text { Make fewer delivery } \\
\text { mistakes }\end{array}$ \\
\hline & Improve level and type of recycling & \\
\hline
\end{tabular}




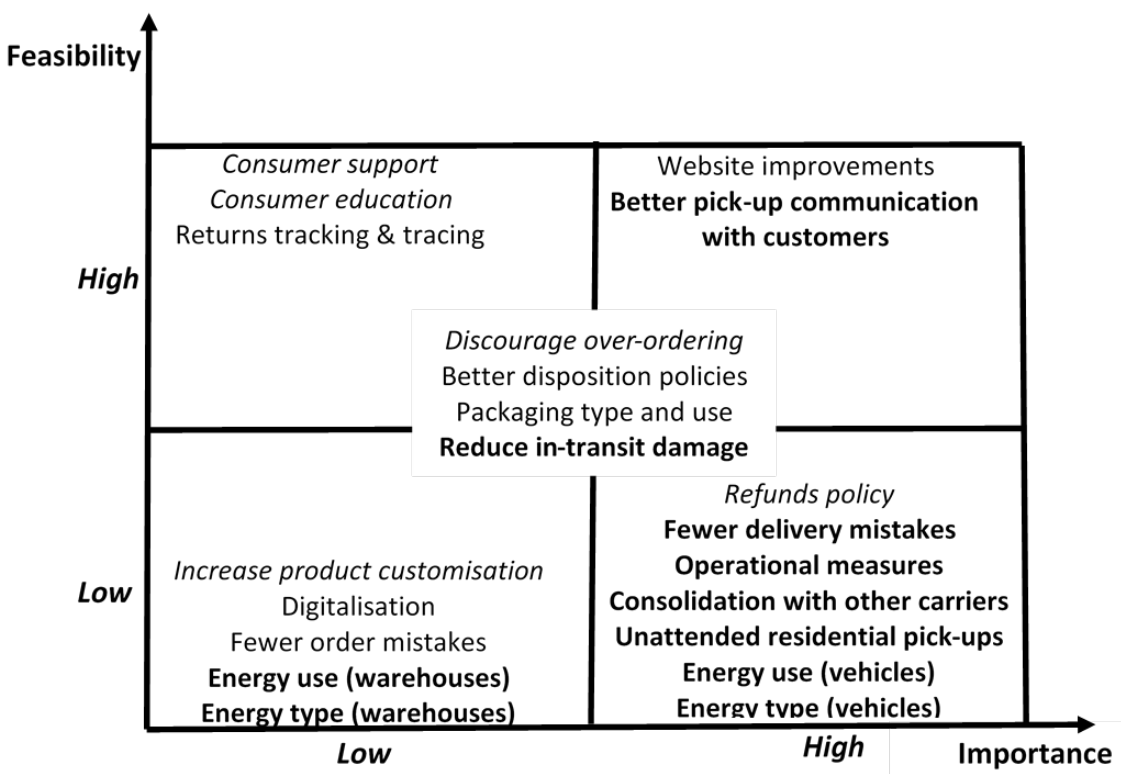

Figure 9. The importance/feasibility matrix populated with measures to reduce returns. Notes: 1) There is no statistical relevance to the order of the measures in each quadrant; 2) Consumer-, carrier- and retailer-oriented measures are shown, respectively, in italics, bold and standard text.

importance and feasibility of the various customer measures cannot be validated and would, therefore, constitute a good area for further research.

\section{Discussion and Conclusions}

Although based on small and not necessarily random samples, this paper has illustrated some of the difficulties of trying to establish the environmental impacts of clothing returns. Retailers selling online are loathe to make clothing returns more difficult or expensive for the consumer, particularly as there is some evidence that consumers who make the most returns also spend more (Davis et al., 1998; Zhang et al., 2017; Klarna, 2019). It is also difficult to increase the price of clothes to cover the cost of the high return rate. Faced with the inevitability of seeking to minimize logistics costs, therefore, some retailers are constructing reverse logistics chains that are imposing considerable costs on the environment.

Clothing returns are increasing and the environmental consequences of these returns are considerable. It is clear that returns create a large number of extra kilometers on the roads; in cars (by people driving to return goods), vans and heavy goods vehicles. Whilst clothing is responsible for the greatest number of returns, other product categories also have a high volume of returns; adding to the total energy use, GHG emissions and pollution attributable to returns.

There are a variety of scenarios which could take place in the future. Under a scenario where the current volume of online orders and associated returns rate remains stable into the future, the sustainability of the returns process can be improved, depending on the speed with which the efficiency of returns handling increases over time. In contrast, if the returns rate stays the same but online or- 
ders increase or, alternatively, if both the volume of online orders and the returns rate were to increase, then the environmental sustainability of the returns process is likely to decrease over time, with the degree to which it deteriorates depending on the measures taken to ameliorate it. Thus, the size of the "possibility gap" depends on the effectiveness of the measures taken to reduce the environmental footprint of the process. However, consumer behavior shows no real tendency to change at present. Indeed, it is younger people who have the highest return rates. If they continue to have a high propensity to return over time (i.e. as they get older) and new generations of consumers behave in the same way, then it appears that an increase in both the volume of online sales and the returns rate is the most likely future scenario. This is borne out by statistics (IMRG, 2020) which shows that the returns rate has been increasing over time in many countries over the past ten years. Under any and all scenarios, therefore, it is important that measures are taken to reduce the energy use and environmental impacts of the returns process and the reverse logistics associated with it.

Given the impracticality, and perhaps even futility, of attempting to calculate precise environmental impacts in relation to the returns to specific retailers (see arguments presented on this matter by McKinnon, 2010; McKinnon, 2012; Mckinnon \& Piecyk, 2012), this paper has instead presented a framework by which measures to decrease the overall footprint can be considered. It could be argued that this is a more fruitful approach to improving environmental sustainability. For instance, it could be postulated that it is better for the environment that the number of returns is reduced to start with, rather than to change the location of a warehouse dealing with returns. This is particularly the case since reducing the number of returns reduces all sorts of incidental waste, including clothes that cannot be resold, the ensuant packaging and the resources involved in dealing with returns processing.

The analysis conducted herein has identified measures which can be taken. It has identified them in terms of the actors involved (consumers, retailers and carriers), the processes involved (mitigation, gatekeeping, collection, sorting and disposal) and the measure types (reducing the number of returns, increasing the efficiency of the returns process and improving the environmental credentials of the assets used). By constructing an importance/feasibility matrix and developing a table of measures, it has also revealed which measures companies should concentrate on in order to best minimize the environmental impact of the returns process.

Retailers are slowly coming to terms with the issue of returns, mainly because of their impact on company profitability, but a major issue to emerge from the analysis is that of the uncertainty surrounding which measure(s) to focus on in order to best reduce the environmental impacts of returns. As with many aspects concerning logistics and the environment, however, some of the easier measures which can be taken to reduce the impacts are "green gold" in terms of both improving the environment whilst at the same time, reducing costs. Most of the measures which can be taken, however, require considerable investment if they 
are to be implemented properly and, even then, there is no guarantee that investing in any of the measures will have the desired effect. The logistics trade press is full of examples of the failures associated with well-intentioned, but ill-conceived or poorly-operationalized, expenditure on logistics systems. The framework developed above could, however, help retailers to focus on their own situation and to analyze where their own specific investment would best be targeted. In this respect, communication with customers has been found to be of key importance, in order to ensure that the gap between the product information they receive when purchasing in-store and that which they receive when ordering a product online is minimized.

Based on the results of this research, one area for future study clearly lies in developing an appropriate approach or methodology for assessing the relative environmental footprint of online versus physical shopping. There is some evidence from our study that retailers with a physical store presence have shorter reverse logistics chains, since customers can take their returns to the store and the returns are then dealt with in situ. This hypothesis needs further testing. Of course, when assessing the overall environmental footprint of returns, it must be taken into account that the physical store has an environmental footprint of its own. However, returns have only a very small marginal additional impact on this, as few extra resources are dedicated to returns.

\section{Acknowledgements}

The authors would like to acknowledge the other members of the research team: Michael Browne, Yingli Wang and Elisabeth Karlsson. In addition, thanks are also due to Energimyndigheten (the Swedish Energy Agency) for funding the project (Project No; 43182-1) and to an anonymous reviewer for providing useful feedback on an earlier version of the paper.

\section{Conflicts of Interest}

The authors declare no conflicts of interest regarding the publication of this paper.

\section{References}

Alumur, S. A., Nickel, S., Saldanha-da-Gama, F., \& Verter, V. (2012). Multi-Period Reverse Logistics Network Design. European Journal of Operational Research, 220, 67-78. https://doi.org/10.1016/j.ejor.2011.12.045

Barclaycard (2018). Snap and Send Back. https://www.home.barclaycard/media-centre/press-releases/snap-and-send-back.html

Bower, A., \& Maxham III, J. G. (2012). Return Shipping Policies of Online Retailers: Normative Assumptions and the Long Term Consequences of Fee and Free Returns. Journal of Marketing, 76, 110-124. https://doi.org/10.1509/jm.10.0419

Bryman, A., \& Bell, E. (2007). Business Research Methods (2nd ed.). Oxford: Oxford University Press.

Buldeo Rai, H., Mommens, K., Verlinde, S., \& Macharis, C. (2019). How Does Consum- 
ers' Omnichannel Shopping Behaviour Translate into Travel and Transport Impacts? Case-Study of a Footwear Retailer in Belgium. Sustainability, 11, 2534. https://doi.org/10.3390/su11092534

Creswell, J. W. (2014). Research Design (4th ed.). Thousand Oaks, CA: SAGE.

Croxton, K. L., Lambert, D. M., García-Dastugue, S. J., \& Rogers, D. S. (2002). The Demand Management Process. The International Journal of Logistics Management, 13, 51-66. https://doi.org/10.1108/09574090210806423

Cullinane, S. L. (2009). From Bricks to Clicks: The Impact of Online Retailing on Transport and the Environment. Transport Reviews, 29, 759-776. https://doi.org/10.1080/01441640902796364

Cullinane, S. L., \& Cullinane, K. P. B. (2018). The Reverse Logistics of Cross-Border e-Tailing in Europe: Developing a Research Agenda to Assess the Environmental Impacts. International Journal of Applied Logistics, 8, 1-19. https://doi.org/10.4018/IJAL.2018010101

Cullinane, S. L., Browne, M., Karlsson, E., \& Wang, Y. (2019). Retail Clothing Returns: A Review of Key Issues. In P. Wells (Ed.), Contemporary Operations and Logistics (pp. 301-322). Cham: Palgrave Macmillan. https://doi.org/10.1007/978-3-030-14493-7_16

Cullinane, S. L., Browne, M., Wang, Y., \& Karlsson, E. (2018). Energy and Environmental Effects of the Reverse Logistics of e-Tailing. Final Report to the Swedish Energy Agency (Energimyndigheten), Gothenburg: University of Gothenburg.

Daaboul, J., Le Duigou, J., Penciuc, D., \& Eynard, B. (2014). Reverse Logistics Network Design: A Holistic Life Cycle Approach. Journal of Remanufacturing, 4, Article No. 7. https://doi.org/10.1186/s13243-014-0007-y

Davis, S., Hagerty, M., \& Gerstner, E. (1998). Return Policies and the Optimal Level of "Hassle". Journal of Economics and Business, 50, 445-460. https://doi.org/10.1016/S0148-6195(98)00013-7

de Brito, M. P., \& Dekker, R. (2003). Modelling Product Returns in Inventory Control-Exploring the Validity of General Assumptions. International Journal of Production Economics, 81-82, 225-241. https://doi.org/10.1016/S0925-5273(02)00275-X

Dekker, R., Fleischmann, M., Inderfurth, K., \& Van Wassenhove, L (Eds.) (2004). Reverse Logistics: Quantitative Models for Closed-Loop Supply Chains. Berlin, Heidelberg: Springer. https://doi.org/10.1007/978-3-540-24803-3

E-Commerce Europe (2019). https://ecommercenews.eu/23-of-ecommerce-in-europe-is-cross-border/

eMarketer (2016). Clothing Tops Shopping List Cross-Border Shoppers Worldwide. https://www.emarketer.com/Article/Clothing-Tops-Shopping-List-Cross-Border-Shop pers-Worldwide/1014776

European Commission (2017). Guarantees and Returns. https://europa.eu/youreurope/citizens/consumers/shopping/guarantees-returns/index_ en.htm

Eurostat (2017).

http://ec.europa.eu/eurostat/statistics-explained/index.php/E-commerce_statistics_for_ individuals

Eurostat (2020). Online Purchases EU 28, 2018.

https://ec.europa.eu/eurostat/statistics-explained/index.php?title=File:Online_purchase s,_EU28,_2018_(\%25_of_individuals_who_bought_or_ordered_goods_or_services_ove r_the_internet_for_private_use_in_the_previous_12_months).png

Frederick, J. (2015). Online Retail Cross-Border Sales: The Global Trend That's Here to 
Stay. Pfsweb.com.

https://www.pfscommerce.com/PDF/whitepapers/Online-Retail-Cross-Border-Sales-FI NAL.pdf?x18118

Golicic, S. L., \& Davis, D. F. (2012). Implementing Mixed Methods Research in Supply Chain Management. International Journal of Physical Distribution and Logistics Management, 42, 726-741. https://doi.org/10.1108/09600031211269721

Griffis, S., Rao, S., Goldsby, T. J., \& Niranjan, T. (2012). The Customer Consequences of Returns in Online Retailing: An Empirical Analysis. Journal of Operations Management, 30, 282-294. https://doi.org/10.1016/j.jom.2012.02.002

Harris, L. (2010). Fraudulent Consumer Returns: Exploiting Retailers Returns Policies. European Journal of Marketing, 44, 730-747. https://doi.org/10.1108/03090561011032694

Harrison III, R. L. (2013). Using Mixed Methods Designs in the Journal of Business Research, 1990-2010. Journal of Business Research, 66, 2153-2162. https://doi.org/10.1016/j.jbusres.2012.01.006

Hjort, K., \& Lantz, B. (2016). The Impact of Returns Policies on Profitability: A Fashion e-Commerce Case. Journal of Business Research, 69, 4980-4985. https://doi.org/10.1016/j.jbusres.2016.04.064

Hjort, K., Hellstrom, D., Karlsson, S., \& Oghazi, P. (2019). Typology of Practices for Managing Consumer Returns in Internet Retailing. International Journal of Physical Distribution and Logistics Management, 49, 767-790. https://doi.org/10.1108/IJPDLM-12-2017-0368

Hjort, K., Lantz, B., Ericsson, D., \& Gattorna, J. (2013). Customer Segmentation Based on Buying and Returning Behavior. International Journal of Physical Distribution and Logistics Management, 43, 852-865. https://doi.org/10.1108/IJPDLM-02-2013-0020

IMRG (2020). IMRG Returns Review-2020. London: IMRG. https://www.imrg.org/data-and-reports/imrg-reports/imrg-returns-review-2020/

Janakiraman, N., \& Ordonez, L. (2012). Effect of Effort and Deadlines on Consumer Product Returns. Journal of Consumer Psychology, 22, 260-271. https://doi.org/10.1016/j.jcps.2011.05.002

Janakiraman, N., Syrdal, H. A., \& Freling, R. (2016). The Effect of Return Policy Leniency on Consumer Purchase and Return Decisions: A Meta-Analytic Review. Journal of Retailing, 92, 226-235. https://doi.org/10.1016/j.jretai.2015.11.002

JDA \& Centiro (2017). Customer Pulse Report. Scottsdale: JDA Software Group. http://now.jda.com/rs/366-TWM-779/images/Customer\%20Pulse\%202017\%20Europe an\%20Comparison.pdf

JDA \& Centiro (2018). Your Customers Have the Answers: Global Consumer Survey Findings Report. Scottsdale: JDA Software Group. https://now.jda.com/rs/366-TWM-779/images/JDA-Centiro-2018-Global-Consumer-S urvey-European-Report.pdf

Katz, K. (2017). CEO Neiman Marcus, World Retail Congress, quoted in JDA and Centiro Customer pulse report, JDA Software Group, Scottsdale.

Kim, J., \& Wansink, B. (2012). How Retailers' Recommendation and Return Policies alter Product Evaluations. Journal of Retailing, 88, 528-541. https://doi.org/10.1016/j.jretai.2012.04.004

Kim, T. Y., Dekker, R., \& Heij, C. (2017). Cross-Border Electronic Commerce: Distance Effects and Express Delivery in European Union Markets. International Journal of Electronic Commerce, 21, 184-218. https://doi.org/10.1080/10864415.2016.1234283 
Klarna (2019). Re-Thinking Returns: The New Norm. And It's Here to Stay. Stockholm: Klarna Confidential. https://www.klarna.com/assets/sites/3/2019/11/14080024/6310-KLA-Re-thinking-Retu rns_DD1-28.02.191.pdf

Lambert, S., Riopel, D., \& Abdul-Kader, W. (2011). A Reverse Logistics Decisions Conceptual Framework. Computers \& Industrial Engineering, 61, 561-581. https://doi.org/10.1016/j.cie.2011.04.012

Larsen, S. B., \& Jacobsen, P. (2016). Revenue in Reverse? An Examination of Reverse Supply Chain Enabled Revenue Streams. International Journal of Physical Distribution and Logistics Management, 46, 783-804. https://doi.org/10.1108/IJPDLM-03-2015-0054

Mangiaracina, R., Marchet, G., Perotti, S., \& Tumino, A. (2015). A Review of the Environmental Implications of $\mathrm{B} 2 \mathrm{C}$ e-Commerce: A Logistics Perspective. International Journal of Physical Distribution and Logistics Management, 45, 565-591. https://doi.org/10.1108/IJPDLM-06-2014-0133

McKinnon, A. C. (2010). Product-Level Carbon Auditing of Supply Chains: Environmental Imperative or Wasteful Distraction? International Journal of Physical Distribution and Logistics Management, 40, 42-60. https://doi.org/10.1108/09600031011018037

McKinnon, A. C. (2012). Carbon Measurement of Supply Chains: Getting the Level Right. In Outlook on the Logistics and Supply Chain Industry. Geneva, Switzerland: World Economic Forum.

McKinnon, A. C., \& Piecyk, M. (2012). Setting Targets for Reducing Carbon Emissions from Logistics: Current Practice and Guiding Principles. Carbon Management, 3, 629-639. https://doi.org/10.4155/cmt.12.62

McKinsey \& Co. (2018). The State of Fashion 2018. https://www.mckinsey.com/ /media/McKinsey/Industries/Retail/Our\%20Insights/Ren ewed\%20optimism\%20for\%20the\%20fashion\%20industry/The-state-of-fashion-2018-fi nal.ashx

Metapack (2020). Global e-Commerce Consumer Report 2020. https://www.metapack.com/resources/

Modell, S. (2010). Bridging the Paradigm Divide in Management Accounting Research: The Role of Mixed Methods Approaches. Management Accounting Research, 21, 124-129. https://doi.org/10.1016/j.mar.2010.02.005

Mollenkopf, D. A., Frankel, R., \& Russo, I. (2011). Creating Value through Returns Management: Exploring the Marketing-Operations Interface. Journal of Operations Management, 29, 391-403. https://doi.org/10.1016/j.jom.2010.11.004

Mollenkopf, D., \& Closs, D. J. (2005). The Hidden Value in Reverse Logistics. Supply Chain Management Review, 9, 34-43.

Pei, Z., Paswan, A., \& Yan, R. (2014). E-Tailers Return Policy, Consumers Perception of Return Policy Fairness and Purchase Intention. Journal of Retailing and Consumer Services, 21, 249-257. https://doi.org/10.1016/j.jretconser.2014.01.004

Petersen, J. A., \& Kumar, V. (2009). Are Product Returns a Necessary Evil? Antecedents and Consequences. Journal of Marketing, 73, 35-51.

https://doi.org/10.1509/jmkg.73.3.035

Piron, F., \& Young, M. (2000). Retail Borrowing: Insights and Implications on Returning Used Merchandise. International Journal of Retail and Distribution, 28, 27-36. https://doi.org/10.1108/09590550010306755

Ramanathan, R. (2011). An Empirical Analysis on the Influence of Risk on Relationships 
between Handling of Product Returns and Customer Loyalty in E-Commerce. International Journal of Production Economics, 130, 255-261.

https://doi.org/10.1016/j.ijpe.2011.01.005

Reagan, C. (2016).

https://www.cnbc.com/2016/12/16/a-260-billion-ticking-time-bomb-the-costly-busines s-of-retail-returns.html

Remy, N., Speelman, E., \& Swartz, S. (2016). Style That's Sustainable: A New Fast Fashion Formula. New York: McKinsey \& Company.

RLA (2016). What Is Reverse Logistics? Research Logistics Association.

Rogers, D., \& Tibben-Lembke, R. (1998). Going Backwards: Reverse Logistics Trends and Practices. Reverse Logistics Executive Council, Reno, NV: University of Nevada.

Rosenbaum, M., \& Bitner-Olson, L. (1999). An Analysis of Merchandise Return Patterns in Order to Determine Potential Consumer Abuses and Effects on Traditional Marketing Response Hierarchy Models. Western Decision Sciences Institute Conference, Atlantic City, NJ.

Rosenbaum, M., \& Kuntze, R. (2005). Looking Good at the Retailers' Expense: Investigating Unethical Retail Disposition Behavior among Compulsive Shoppers. Journal of Retailing and Consumer Services, 12, 217-225. https://doi.org/10.1016/j.jretconser.2004.07.001

Rubio, S., Chamorro, A., \& Miranda, F. J. (2008). Characteristics of the Research on Reverse Logistics (1995-2005). International Journal of Production Research, 46, 1099-1120. https://doi.org/10.1080/00207540600943977

Saarijärvi, H., Sutinen, U.-M., \& Harris, L. C. (2017). Uncovering Consumers’ Returning Behavior: A Study of Fashion e-Commerce. The International Review of Retail, Distribution and Consumer Research, 27, 284-299. https://doi.org/10.1080/09593969.2017.1314863

Schwartz, B. (2000). Reverse Logistics Strengthens Supply Chains. Transportation \& Distribution, 41, 95-100.

Shang, G., Pekgün, P., Ferguson, M., \& Galbreth, M. (2017). How Much Do Online Consumers Really Value Free Product Returns? Evidence from eBay. Journal of Operations Management, 53-56, 45-62. https://doi.org/10.1016/j.jom.2017.07.001

Statista.com (2019).

https://www.statista.com/statistics/276846/reach-of-top-online-retail-categories-world wide/

Suwelack, T., Hogreve, J., \& Hoyer, W. D. (2011). Understanding Money-Back Guarantees: Cognitive, Affective, and Behavioral Outcomes. Journal of Retailing, 87, 462-478. https://doi.org/10.1016/j.jretai.2011.09.002

Thomas, G. (2017). Tackling the Returns Process. Focus, December, 44-45.

Wang, J. J. Chen, H., Rogers, D., Ellram, L., \& Grawe, S. (2017). A Bibliometric Analysis of Reverse Logistics Research (1992-2015) and Opportunities for Future Research. International Journal of Physical Distribution \& Logistics Management, 47, 666-687. https://doi.org/10.1108/IJPDLM-10-2016-0299

Yin, R. (2014). Case Study Research: Design and Methods (3rd ed.). London: Sage Publications.

Zhang, J., Li, H., Yan, R., \& Johnston, C. (2017). Examining the Signaling Effect of E-Tailers' Return Policies. Journal of Computer Information Systems, 57, 191-200. https://doi.org/10.1080/08874417.2016.1183989 